\title{
Hydrocarbon-degrading bacteria in Colombia: systematic review
}

\author{
Diana Carolina Rache-Arce ${ }^{\mathbb{D}}$. \\ Maryuris Machacado-Salas (iD) \\ Doris Rosero-García
}

Received: 30 November 2020 / Accepted: 12 February 2022 / Published online: 2 March 2022

(C) The Author(s) 2022

\begin{abstract}
Petroleum industry activities worldwide have caused pollution and resulted in environmental degradation. Microorganisms with the potential to reduce pollutant levels by degradation processes have been reported, and bacteria are among such organisms. The first study on bacterial degradation in Colombia was published in 1996. The study isolated bacteria belonging to the Pseudomonas genus from hydrocarbon-polluted sediments. Since then, different reports on degrading bacteria have been published. The objective of this systematic review is to identify and analyze all the studies on hydrocarbon-degrading bacteria performed in Colombia. To accomplish this goal, a literature search was conducted. Inclusion and exclusion criteria were applied, and 37 relevant articles were obtained. We found that 2018 was the year with the largest number of publications in Colombia, and most frequently identified bacterial genera were Pseudomonas and Bacillus. Some studies showed that the degradation of hydrocarbons is more efficient when bacterial consortia are used rather than pure cultures. This study provides information about bacteria with the potential to degrade hydrocarbons in
\end{abstract}

D. C. Rache-Arce - M. Machacado-Salas .

D. Rosero-García $(\bowtie)$

Grupo de Investigación en Microbiología, Industria y Ambiente (GIMIA), Facultad de Ciencias Básicas, Universidad Santiago de Cali, Calle 5 \# 62-00 Barrio Pampalinda, Santiago de Cali, Valle del Cauca, Colombia e-mail: doris.rosero@udea.edu.co
Colombia, which in turn will be a source of information for future studies in this field.

Keywords Bacteria $\cdot$ Colombia $\cdot$ Degradation . Hydrocarbons

\section{Introduction}

Petroleum hydrocarbons are fossil fuels formed from organic matter; which are distributed in the subsoil layers and used for industrial energy production worldwide (Velásquez- Arias 2017). Currently, the presence of various kind of automobiles, the use of cleaning solvents, and some cosmetics may contain large amounts of hydrocarbons, which has caused an increase in their use (Ahmed and Fakhruddin 2018). The petroleum industry has grown in Colombia in recent years. The reserves of this fossil fuel are estimated to be about 1.5 billion barrels, which represents $26 \%$ of the country's exports (HernándezRodríguez 2020). The growth of this industry has provided many benefits to the national economy by actively contributing to exports and the production of goods. The sector has further stimulated the generation of jobs and royalties for the financing of public expenditure (Hernández-Rodríguez 2020). However, unfortunately, petroleum sources also contribute to pollution and changes in land use as well as surface and groundwater utilization owing to exploitation, refining, lack of maintenance, and fuel theft (Sales 
da Silva et al. 2020). Moreover, Colombia has been affected by terrorist attacks approximately 829 times between 2007 and 2015 caused spills of thousands of barrels of hydrocarbons (Mendizabala et al. 2021). These problems may affect terrestrial and aquatic biodiversity due to landscape alteration (Sales da Silva et al. 2020).

In the abovementioned context, microorganisms with the potential to reduce pollutant levels by degradation processes have gained attention (Garzón et al. 2017; Sales da Silva et al. 2020). Bacteria are among those microorganisms that are able to convert the pollutants to less toxic molecules, and hence, allow the reclamation of large expanses of polluted areas (Hernández Ruiz et al. 2017; Renteria and Rosero 2019). Bacteria are capable of tolerating and using certain pollutants as sources of carbon and energy, contributing to the remediation of affected ecosystems (Marquez-Rocha et al. 2001). The oxygendependent enzymes called monooxygenases provide a means to use hydrocarbons as substrates, which allows the survival of bacteria in hydrocarbon-polluted environments (Das and Chandran 2011). Certain bacteria isolates such as Escherichia coli, Alcaligenes sp. and Thiobacter subterraneus can contribute in the degradation process by combining several metabolic pathways in a consortium to increase the extent of degradation of polycyclic aromatics hydrocarbonsPAHs (Pandey and Dubey 2012). Another important aspect is the presence of indigenous bacterial populations, which are of interest in degradation studies as they can be directly isolated from polluted sites and be characterized for a better understanding of the mechanism of biodegradation (Das and Chandran 2011).

The first study on bacterial degradation in Colombia, published in 1996, isolated bacteria belonging to the Pseudomonas genus from sediments highly polluted by PAHs (Vargas et al. 1996). Since then, several studies have been published, including reviews that list hydrocarbon-degrading bacteria (HDB) and discuss the importance of their management in polluted environments (Lozano 2005; Benavides-López et al. 2006; Trujillo-Toro and Ramírez-Quirama 2012; Garzón et al. 2017; De La Rosa Martinez and RabeloFlorez 2020). However, thus far, there is no known review gathering data from all the research on hydrocarbon-degrading bacteria, advantages, and applications in Colombia. Since the problem of hydrocarbon pollution is of global relevance (Zhang and Chen 2017; Sales da Silva et al. 2020) and Colombia also considers it a critical issue. Therefore, in this review the objective is to identify all the studies on HDB conducted in the country so far. This paper provides an analysis about bacterial hydrocarbon degradation capability, pinpoint the areas in which degradation studies have been performed, and identify the most evaluated hydrocarbon. This information towards the better understanding in bioremediation challenges and will allow researchers interested in this field to have adequate baseline information to plan future studies.

\section{Materials and methods}

Investigations were selected from the Scielo, PubMed, Redalyc, ScienceDirect, Scopus, and Dialnet databases. Google Scholar was also used for the search of gray literature, and for peer reviewed articles. The following keywords were defined in Spanish (degradación, Colombia, hidrocarburos, bacterias), and in English (degradation, Colombia, hydrocarbon, bacteria). Different combinations of last keywords were employed to obtain a high number of publications in the exhaustive search. For the selection of publications suitable for analysis, the following inclusion criteria were established: type of study (original articles and theses), place (Colombia), degraded pollutant (petroleum, diesel, gasoline, motor oil), degrading microorganism (bacteria), publication date (between 1996 and 2021), and language (Spanish and English). During the literature search, those articles that did not meet the established criteria were excluded: articles about studies performed outside Colombia, degrading organisms other than bacteria, such as fungi, microalgae, and plants, and degraded pollutants other than hydrocarbons, such as heavy metals and pesticides.

The results of the analysis of the collected studies were recorded in a table using Microsoft ${ }^{\circledR}$ Excel 2019 according to author's name, year of publication, 
Table 1 General statistical information for the articles of hydrocarbon-degrading bacteria (until May 2021)

\begin{tabular}{lcr}
\hline Database & Spanish & English \\
\hline Number of articles found in the search results by database \\
Scielo & 59 & 154 \\
PubMed & 0 & 82 \\
Redalyc & 0 & 137 \\
ScienceDirect & 1 & 302 \\
Scopus & 0 & 0 \\
Dialnet & 0 & 1 \\
Google Scholar & 350 & 202 \\
Total number of articles & 410 & 878 \\
\hline
\end{tabular}

source in which the study was conducted, type of study, and identified bacterium (genus and/or species). Additionally, an analysis to determine the behavior and the interest in studying HDB between 1996 and 2021 was performed. The impact and the interest in research on this topic in Colombia were assessed and compared with some reviews performed for other regions of the world.

\section{Results}

The exhaustive search yielded 1288 articles, 410 of which were published in Spanish and 878 in English (Table 1).

After removal of the duplicate articles and application of the inclusion criteria, 37 articles were obtained (Fig. 1).

From the analysis of the 37 selected publications, it was observed that a high number of studies on bacterial hydrocarbon degradation were published mainly in 2018 (Fig. 2). This study was done in Colombia's subnational territories, which comprise Bogotá as Capital District (C.D.), and 32 political-administrative entities called departments. Moreover, the country is divided into six natural regions constituted by differences in topography, weather, vegetation, types of soil and oil production. The Andean Region, covering the three branches of the Andes mountains; the Caribbean Region, covering the area adjacent to the
Scielo: 213

PubMed: 82

Redalyc: 137

ScienceDirect: 303

Scopus: 0

Dialnet: 1

Google Scholar: 552
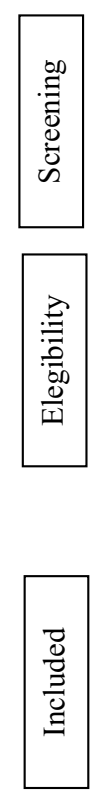

Studies included per database

Scielo: 9

PubMed: 2

Redalyc: 3

ScienceDirect: 3

Dialnet: 3

Google Scholar: 17

Fig. 1 PRISMA flowchart showing the selection of the research articles of hydrocarbon-degrading bacteria in Colombia

Caribbean Sea; the Pacific Region adjacent to the Pacific Ocean; the Orinoquía Region, part of the Llanos plains mainly in the Orinoco River basin along the border with Venezuela; the Amazon Region, part of the Amazon rainforest; and finally the Insular Region, comprising islands in both the Atlantic and Pacific oceans (Fig. 3). Among the departments in which a high number of studies on HDB have been conducted are Antioquia and Cundinamarca with eight and seven publications respectively, located at Andean Region with a oil production of 319 Million barrels per day in 2020 (Minenergía 2021). 
Fig. 2 Number of studies on HDB in Colombia between 1996 and 2020

Fig. 3 Map of Colombia showing the number of publications per department and oil production by region
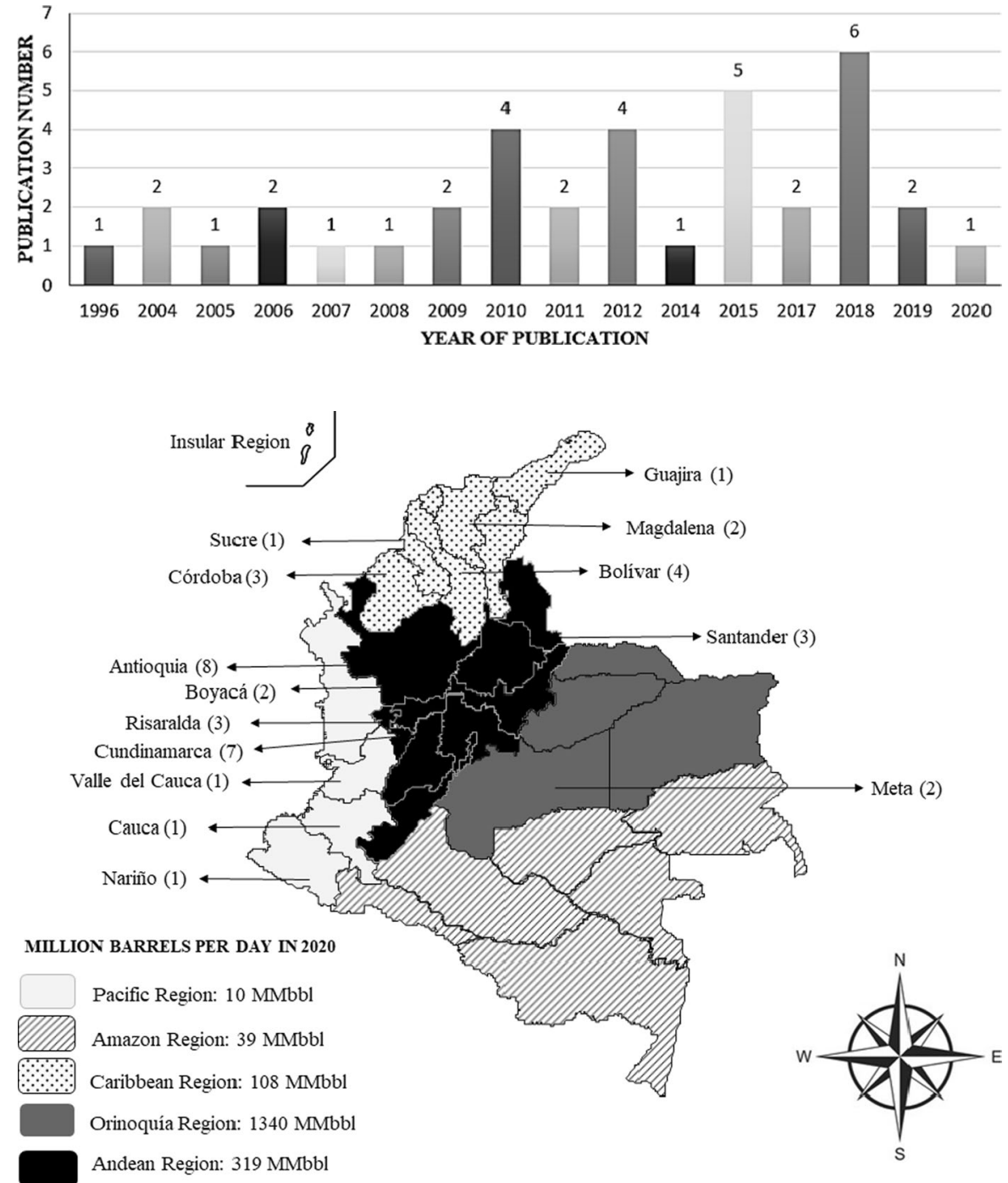

Remarkably, the Orinoquía Region had the highest oil production, but two studies have been conducted only (Fig. 3).

Pseudomonas sp. was the most representative genus of HDB on the papers in Colombia (Table 2). In the present study, 19 publications describing the isolation of bacteria belonging to this genus with Pseudomonas aeruginosa and Pseudomonas putida being the most frequently isolated species (Fig. 4). Furthermore, 7 publications reported bacteria belonging to the Bacillus genus (Table 2). Some studies did not report the bacterial genus and/or species because unidentified strains from bacterial consortia were used (Table 2). Among the analyzed studies, 16 on petroleum, 12 on diesel, 4 on gasoline, 1 on oil motor, 1 on kerosene, and 1 on tar. Three studies did not report the evaluated hydrocarbon (Table 2). In addition, an analysis of the universities, companies, and research groups that participated in the publications was performed (Table 3). The bacterial strains able to degrade hydrocarbons were isolated and identified, from soils samples mainly (Table 2). 


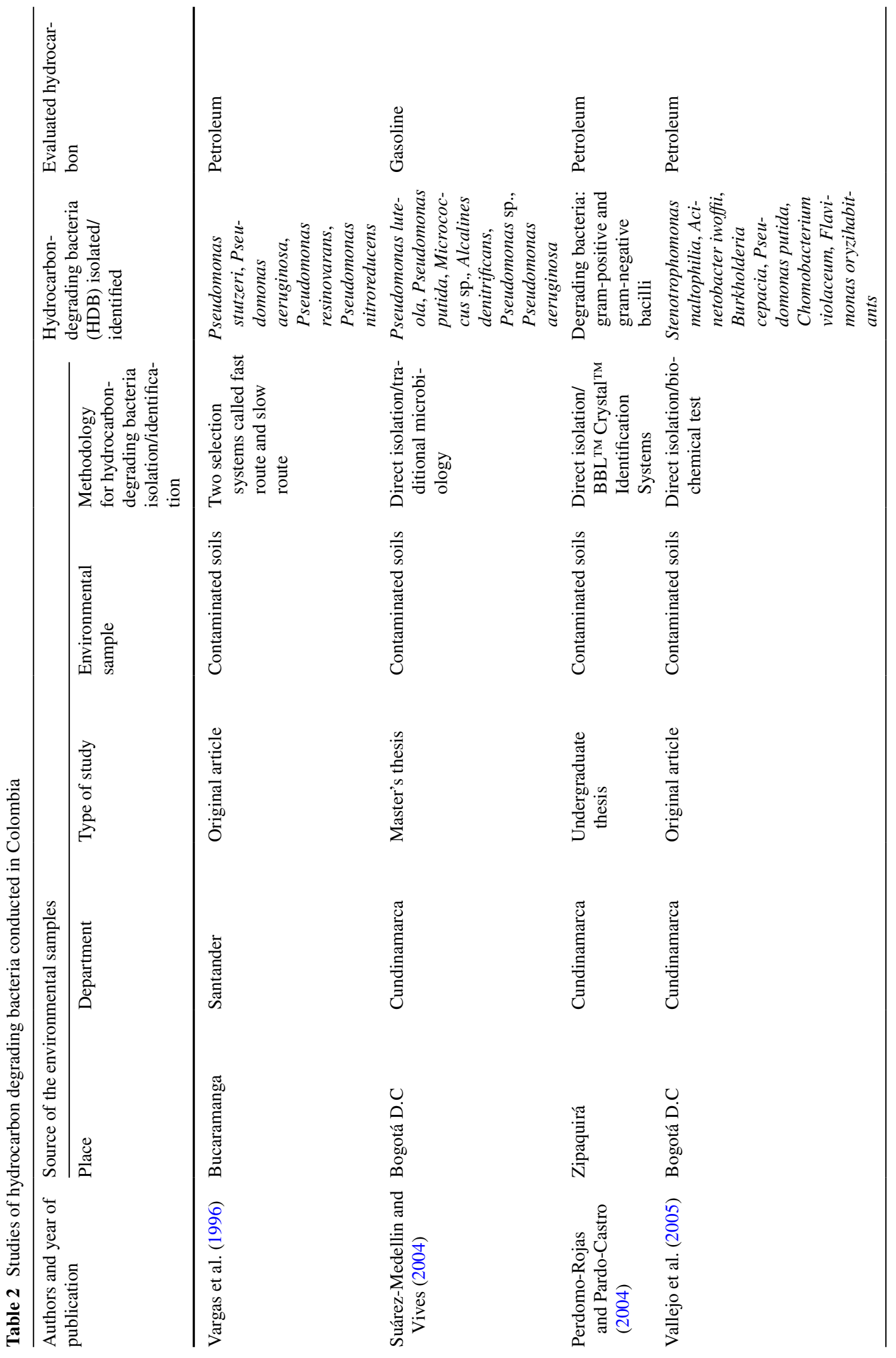




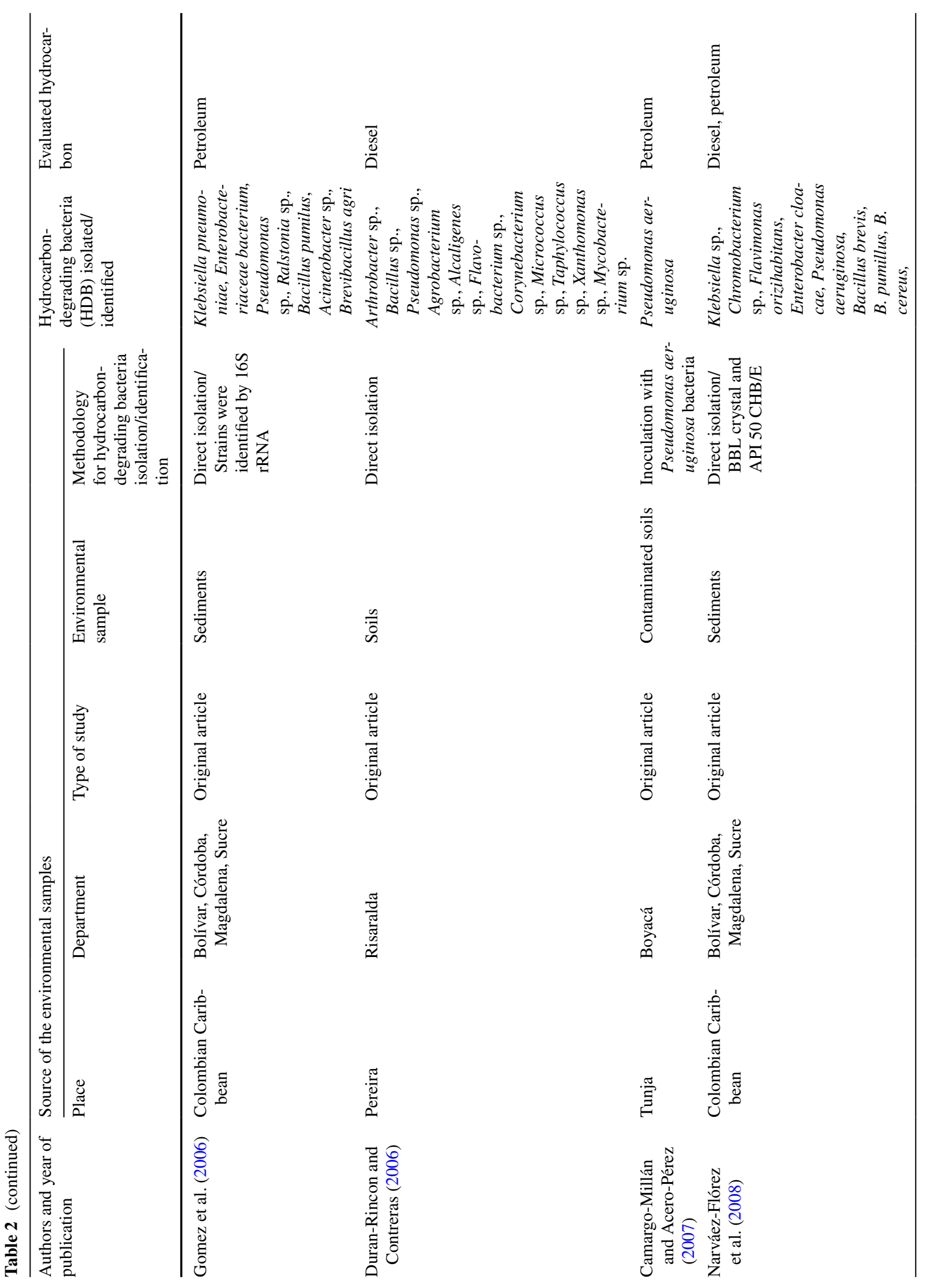




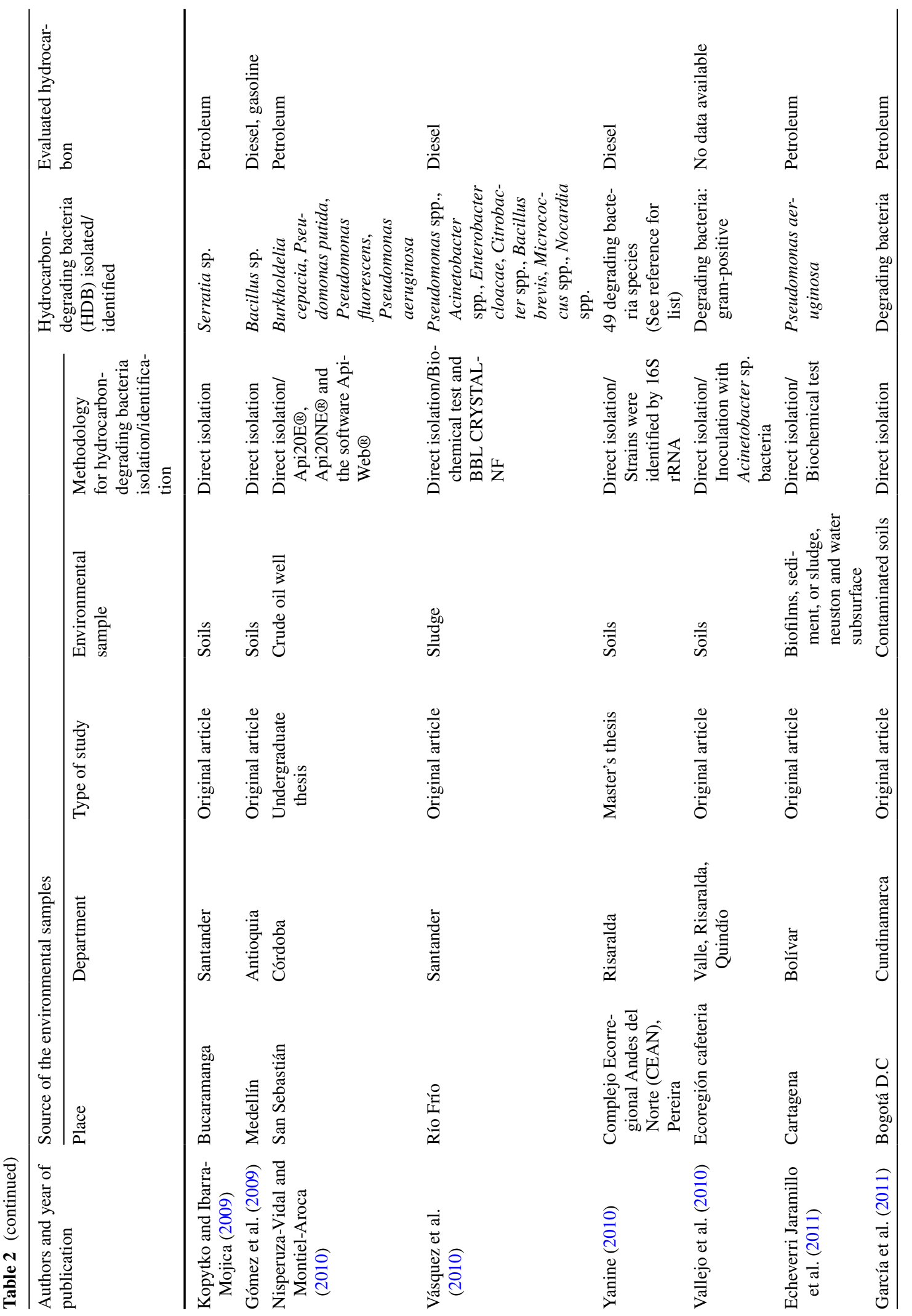




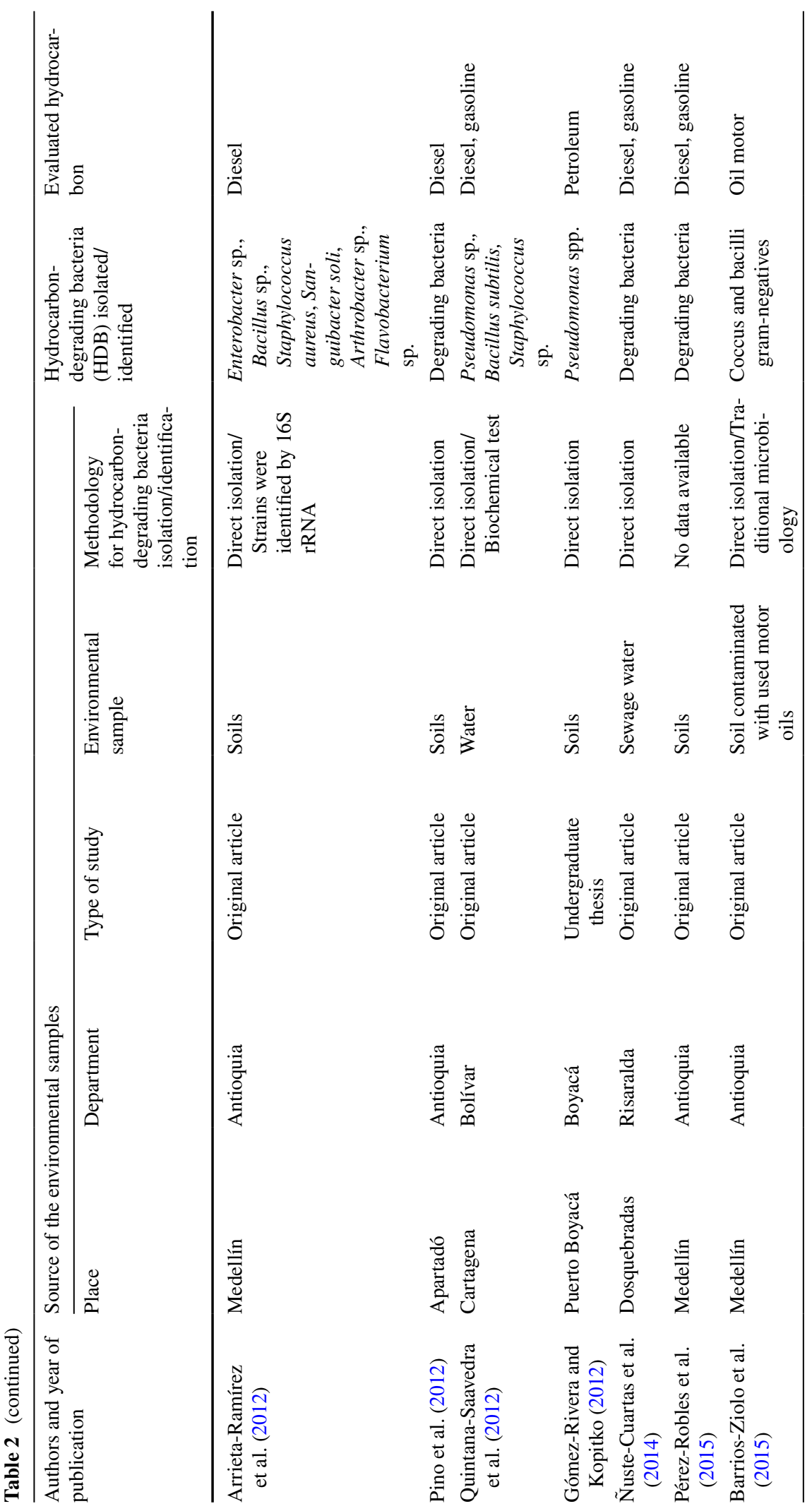




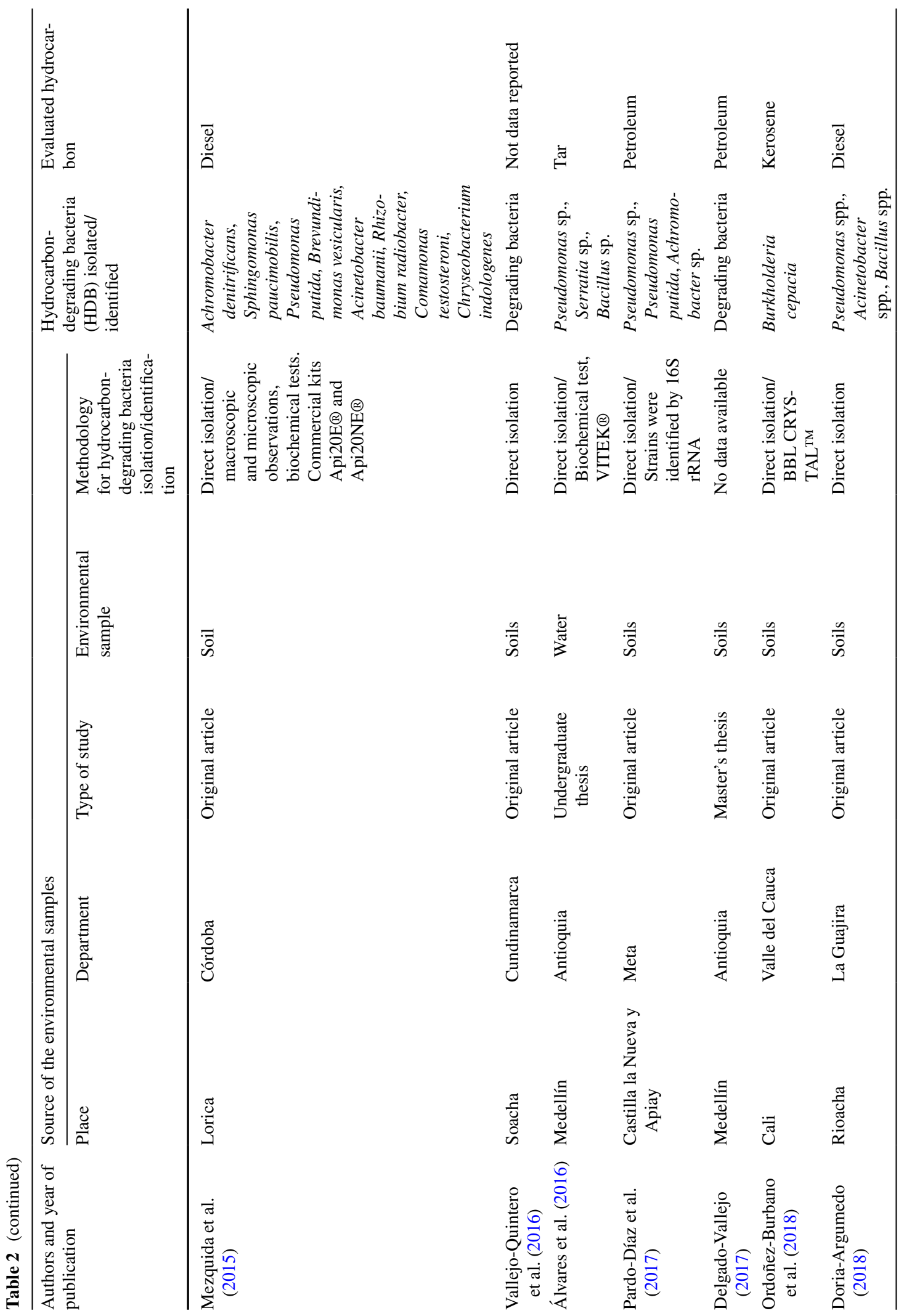




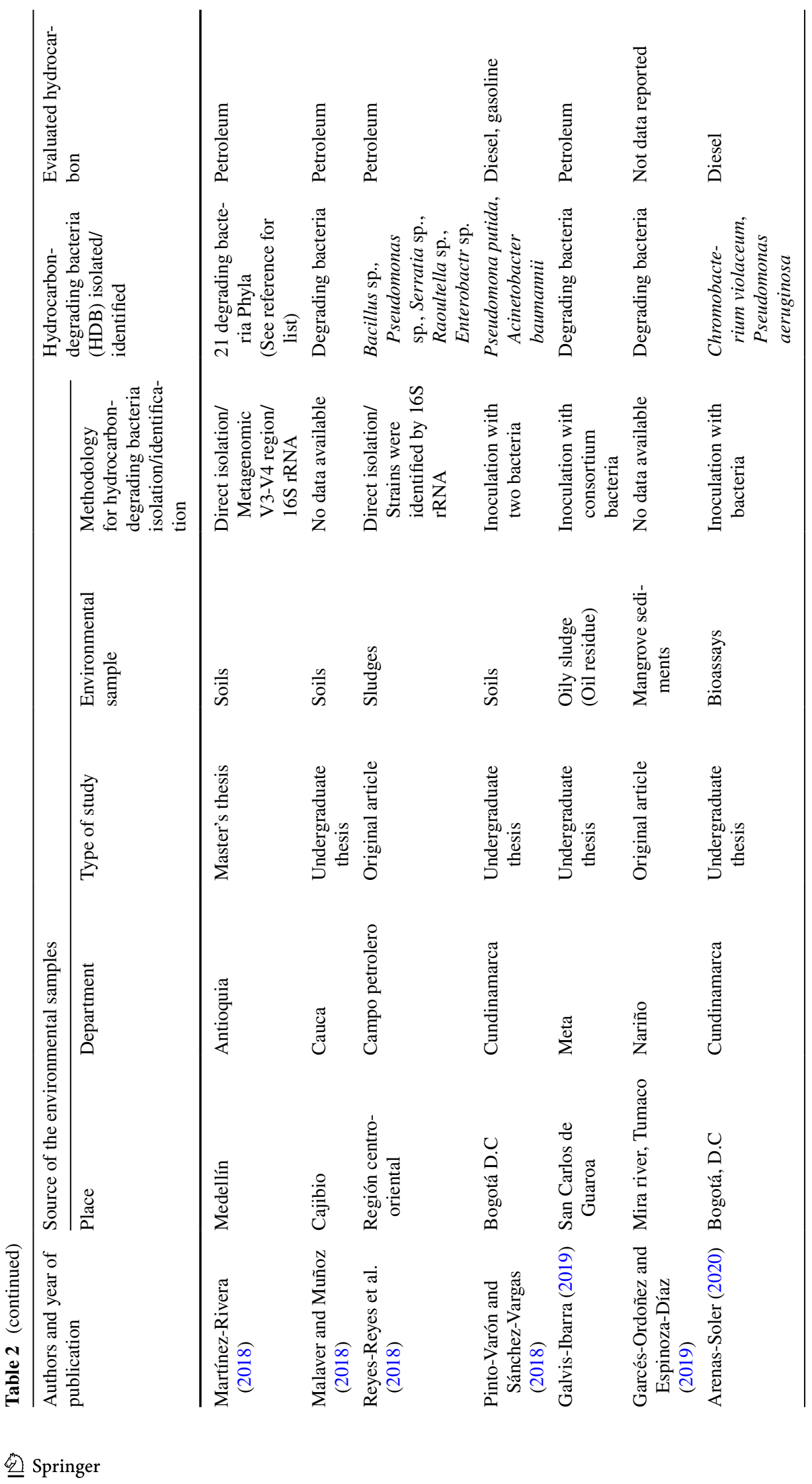




\section{Discussion}

This systematic review was designed to provide the most complete, up-to-date list of studies about hydrocarbon-degrading bacteria (HDB) in Colombia, with a total of 37 investigations. Selecting the HDB is of profound significance in evaluating, developing, and designing strategies for bioremediation studies owing to their potential to adapt to polluted environments and convert the pollutants such as hydrocarbons to innocuous substances by degradation (Das and Chandran 2011). Moreover, it is important to perform studies to identify bacteria with degradation capability like an important step toward successful bioremediation (Reyes-Reyes et al. 2018). In the present review, we found that authors from different universities, companies, and research groups have conducted studies in Colombia to isolate HDB on environmental samples since 1996 (Vargas et al. 1996). For Colombia, 2003 was a year of substantial advances with regard to petroleum exploration given that reforms attracted foreign investment (Trujillo-Quintero et al. 2017). Probably, this is the reason for an increase in publications after 2003. Most of the publications were from 2018, it is likely that the above issue might have aroused the interest of different researchers to study microbial degradation and provide possible solutions for the pollution problem using bioremediation (Renteria and Rosero 2019). Moreover, the increasing available grants to investigations and doctoral formation in last year's support the results obtained here (Minciencias 2019).

In the Andean Region, the departments of Antioquia and Cundinamarca, there are research groups in microbiology, chemical engineering, and biotechnology, among others. This observation emphasizes the fact that this region is very much interested in and at the cutting edge of studies in HDB. Concerning the research groups, the ones belonging to Universidad Nacional de Colombia, particularly in Medellín at Antioquia department, and Pontificia Universidad Javeriana in Bogotá, D.C. at Cundinamarca department reported the highest number of publications on HDB in Colombia. This establishes the need to continue the search for HDB in all the departments of the country, mainly in those located in regions with high oil production where can provide hydrocarbon residues.

The occurrence of some species belonging to the Pseudomonas and Bacillus genera and others mentioned here, constitutes valuable information for HDB present in Colombia. According to the analyzed publications, Pseudomonas and Bacillus species are the most frequently isolated in hydrocarbon degradation studies in the country. Probably, this result could be attributed to the much higher cultivability of both genera by direct isolation of contaminated samples with hydrocarbons (Gomez et al. 2006; QuintanaSaavedra et al. 2012; Álvares et al. 2016; DoriaArgumedo 2018). However, Pseudomonas and Bacillus are genera truly important and have been found to play vital roles in petroleum hydrocarbon degradation (Vásquez et al. 2010; Yanine 2010; Das and Chandran 2011; Xu et al. 2018). For example, P. aeruginosa has been identified as a HDB capable of degrading aromatic and polyaromatic hydrocarbons because it produces biosurfactants during its stationery growth phase, which facilitates the solubilization and therefore the degradation (Silva et al. 2018). Inoculation with $P$. aeruginosa bacteria had the highest rates of hydrocarbon removal, in ground contaminated samples with the Castilla`s crude, coming from 10 fields (Camargo-Millán and Acero-Pérez 2007). Pseudomonas putida is part of the soil microbiota and possesses enzymes called dioxygenases that are involved in hydrocarbon degradation (Truskewycz et al. 2019). On the other hand, species belonging to the Bacillus genus present high adaptability and can grow in extreme and hostile environments such as hydrocarbon contaminated soil and water (de Mesa et al. 2006; Valdivia-Anistro et al. 2018). Furthermore, the Bacillus genus is another bacterium reported as petroleum hydrocarbon degrader, and could be useful in reducing the levels of these hydrocarbons (Kolsal et al. 2017; Lima et al. 2020).

Another important result is taxonomic information for some HDB is unknown (Perdomo-Rojas and Pardo-Castro 2004; Vallejo et al. 2010; Yanine 2010; García et al. 2011). Additional investigations using molecular and other tools to identify all HDB is highly desirable in these cases. Overall, the taxonomy of environmental bacteria in Colombia is relatively 


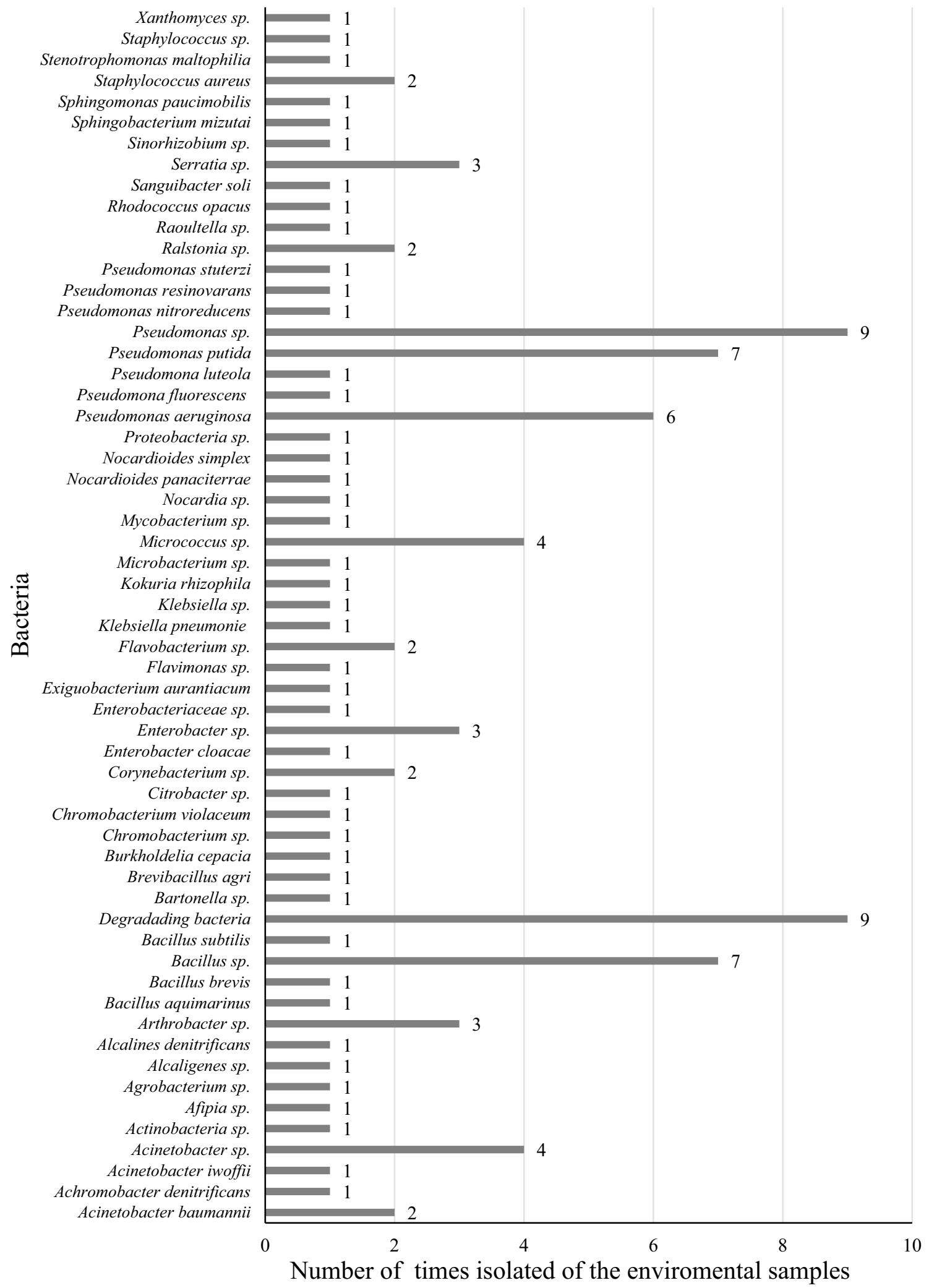


4Fig. 4 Hydrocarbon degrading bacteria (HDB) in Colombia and their frequency in the analyzed publications

poorly known. The taxonomic category of HDB is important for planning and interpreting future biodegradation studies (Ławniczak et al. 2020). In addition, the degradation of hydrocarbons is more effective when bacteria work together in a consortium. For example, Arrieta et al. showed the efficiency of a bacterial consortium that included the genera Arthrobacter, Bacillus, Flavobacterium, Sanguibacter, and Staphylococcus in the degradation of diesel (ArrietaRamírez et al. 2012). Vásquez et al. used a bacterial consortium composed of Acinetobacter, Bacillus brevis, Citrobacter, Enterobacter cloacae, Micrococcus, Nocardia, and Pseudomonas to study the degradation of oil sludge from a car wash (Vásquez et al. 2010). The hydrocarbons evaluated in the 37 selected publications; petroleum was the most studied one. In general, the authors suggest that short-chain aliphatic hydrocarbons such as those found in gasoline are more likely to volatilize and also tend to be toxic for bacteria (Suárez-Medellin and Vives 2004; NarváezFlórez et al. 2008). This fact could explain why there are not as many studies on gasoline degradation as on petroleum.

This systematic review addresses studies specifically performed in Columbia with Columbian environmental samples. A more thorough investigation of knowledge about HDBs in different regions and their role in bioremediation of contaminated sites is useful. There are few similar studies that have systematically reviewed HDBs identified from specific regions or countries around the world. A review of remediation approaches for petroleum hydrocarbon contamination in the Arctic and Antarctic regions included bioremediation and identified bacteria isolated from these regions (Camenzuli and Freidman 2015). A recent review of PAH contamination in China, a country where rapid industrialization and urbanization have created fast economic growth, focused more on sources of PAHs in soils, but not on biodegradation (Zhang and Chen 2017). Other recent reviews examined more generally petroleum hydrocarbon biodegradation in aquifers (Logeshwaran et al. 2018) and provided an overview of enhanced hydrocarbon biodegradation strategies (Ławniczak et al. 2020). Notably, in Colombia a review article provided information regarding the most representative bacterium in biodegrading hydrocarbons Pseudomonas sp., Bacillus sp., Bacillus subtilis and Burkholderia sp. (De La Rosa Martinez and Rabelo-Florez 2020). A compilation of investigations conducted inside a specific country is important for establishing a baseline and needs for future research. This is especially pertinent in countries such as Colombia due to the presence of hydrocarbons as substantial contaminants in different ecosystems throughout the country, and where much research is still needed. We considering that it is also important that similar systematic reviews be conducted by researchers in the different countries to know the HDB and the studies that may be required to control hydrocarbons contamination.

\section{Conclusions}

A literature search yielded 1288 articles on HDB. After applying the inclusion criteria, 37 published studies were identified in Colombia between 1996 and 2020. However, among these, no doctoral theses were found. Most of the publications were from 2018, and Bacillus sp. and Pseudomonas sp. are the most studied genera in Colombia. Particularly, P. aeruginosa and $P$. putida are the most assessed species owing to the metabolic variation and enzymatic production that allow them to adapt to environments polluted with hydrocarbons. It was observed in several studies that hydrocarbon degradation is more efficient when bacterial consortia are used rather than pure cultures. The most studied hydrocarbon in Colombia is petroleum, while the least reported ones are oil motor, kerosene, and tar. Finally, this study is important because it provides useful information about bacteria that exhibit the potential to degrade hydrocarbons in Colombia. 
Table 3 Universities, companies, and research groups that have published on Hydrocarbon Degrading Bacteria (HDB) in Colombia

\begin{tabular}{|c|c|c|c|}
\hline Universities and companies & Research groups or laboratories & \# & Authors and year of publication \\
\hline \multirow[t]{5}{*}{ Universidad Nacional de Colombia } & $\begin{array}{l}\text { Biorremediación y Desarrollo Tec- } \\
\text { nológico }\end{array}$ & 2 & $\begin{array}{l}\text { Delgado-Vallejo (2017); Martínez-Rivera } \\
\text { (2018) }\end{array}$ \\
\hline & $\begin{array}{l}\text { Grupo de investigación en Ciencias de } \\
\text { los Alimentos }\end{array}$ & 1 & Arrieta-Ramírez et al. (2012) \\
\hline & $\begin{array}{l}\text { PARH-Posgrado de Aprovechamiento de } \\
\text { Recursos Hidráulicos }\end{array}$ & 1 & Pérez-Robles et al. (2015) \\
\hline & $\begin{array}{l}\text { Laboratorios de Química de Suelos, } \\
\text { Análisis Instrumental, Microbiología } \\
\text { Molecular y Microbiología Industrial / } \\
\text { Laboratorio de Hidráulica/Laboratorio } \\
\text { de Microbiología Ambiental y Aplicada }\end{array}$ & 3 & $\begin{array}{l}\text { Gómez et al. (2009); Barrios-Ziolo et al. } \\
\text { (2015); Pardo-Díaz et al. (2017) }\end{array}$ \\
\hline & $\begin{array}{l}\text { CIEBREG-Centro de Investigaciones y } \\
\text { Estudios en Biodiversidad y Recursos } \\
\text { Genéticos }\end{array}$ & 1 & Yanine (2010) \\
\hline $\begin{array}{l}\text { Universidad Pedagógica y Tecnológica } \\
\text { de Colombia }\end{array}$ & $\begin{array}{l}\text { GIGA-Grupo de Investigación en } \\
\text { Geomática y Ambiente }\end{array}$ & 1 & Camargo-Millán and Acero-Pérez (2007) \\
\hline Universidad de La Guajira & $\begin{array}{l}\text { Grupo de Investigación Territorios Semi- } \\
\text { áridos del Caribe }\end{array}$ & 1 & Doria-Argumedo (2018) \\
\hline Universidad de los Andes & $\begin{array}{l}\text { CIMIC-Centro de Investigaciones Micro- } \\
\text { biológicas }\end{array}$ & 2 & $\begin{array}{l}\text { Suárez-Medellin and Vives (2004); Gomez } \\
\text { et al. (2006) }\end{array}$ \\
\hline \multirow[t]{2}{*}{ Universidad de San Buenaventura } & $\begin{array}{l}\text { GIMA-Grupo de Microbiología y } \\
\text { Ambiente }\end{array}$ & 1 & Echeverri Jaramillo et al. (2011) \\
\hline & $\begin{array}{l}\text { CIOH-Centro de Investigaciones Ocean- } \\
\text { ográficas e Hidrográficas del Caribe }\end{array}$ & 1 & Quintana-Saavedra et al. (2012) \\
\hline Universidad de Antioquia & $\begin{array}{l}\text { GDCON-Diagnostic and Pollution Con- } \\
\text { trol Group }\end{array}$ & 1 & Pino et al. (2012) \\
\hline Universidad de La Salle & $\begin{array}{l}\text { Laboratorios de Microbiología de la } \\
\text { Universidad de La Salle }\end{array}$ & 2 & $\begin{array}{l}\text { Perdomo-Rojas and Pardo-Castro (2004); } \\
\text { Arenas-Soler (2020) }\end{array}$ \\
\hline \multirow[t]{2}{*}{ Universidad Tecnológica de Pereira } & Agua y Saneamiento & 1 & Ñuste-Cuartas et al. (2014) \\
\hline & $\begin{array}{l}\text { Laboratorio de Oleoquímica de la escuela } \\
\text { de Química }\end{array}$ & 2 & Duran-Rincon and Contreras (2006) \\
\hline \multirow[t]{2}{*}{ Pontificia Universidad Javeriana } & $\begin{array}{l}\text { USBA-Unidad de Saneamiento y Biotec- } \\
\text { nología Ambiental }\end{array}$ & 5 & $\begin{array}{l}\text { Vallejo et al. (2005); García et al. (2011); } \\
\text { Vallejo-Quintero et al. (2016); Pardo- } \\
\text { Díaz et al. (2017); Galvis-Ibarra (2019) }\end{array}$ \\
\hline & A.T.P Ingeniería S.A.S & 1 & Galvis-Ibarra (2019) \\
\hline \multirow[t]{2}{*}{ Universidad Pontifica Bolivariana } & $\begin{array}{l}\text { Centro de Investigación en Biotec- } \\
\text { nología, Biotécnica y Ambiente }\end{array}$ & 1 & Kopytko and Ibarra-Mojica (2009) \\
\hline & SINSA & 1 & Gómez-Rivera and Kopitko (2012) \\
\hline Universidad de Córdoba & $\begin{array}{l}\text { GRUBIODEQ-Grupo de Investigación en } \\
\text { Biotecnología }\end{array}$ & 2 & $\begin{array}{l}\text { Nisperuza-Vidal and Montiel-Aroca } \\
\text { (2010); Mezquida et al. (2015) }\end{array}$ \\
\hline Universidad del Valle & $\begin{array}{l}\text { Laboratorio de Docencia de Microbi- } \\
\text { ología de la Universidad del Valle }\end{array}$ & 1 & Ordoñez-Burbano et al. (2018) \\
\hline Universidad Libre & $\begin{array}{l}\text { Laboratorios de Ingeniería Ambiental de } \\
\text { la Universidad Libre }\end{array}$ & 1 & Pinto-Varón and Sánchez-Vargas (2018) \\
\hline Universidad de Santander & $\begin{array}{l}\text { Laboratorio Clínico de la Universidad de } \\
\text { Santander (UDES) }\end{array}$ & 1 & Vásquez et al. (2010) \\
\hline Fundación Universidad de America & Not information available & 1 & Arenas-Piza (2018) \\
\hline Universidad Industrial de Santander & $\begin{array}{l}\text { Corporación para la Investigación de la } \\
\text { Corrosión }\end{array}$ & 1 & Reyes-Reyes et al. (2018) \\
\hline Universidad central de Colombia & Agua y Desarrollo Sostenible & 1 & Gamba and Pedraza (2017) \\
\hline
\end{tabular}


Table 3 (continued)

\begin{tabular}{|c|c|c|c|}
\hline Universities and companies & Research groups or laboratories & \# & Authors and year of publication \\
\hline $\begin{array}{l}\text { Institución universitaria colegio mayor } \\
\text { de Antioquia }\end{array}$ & Biociencias & 1 & Álvarez-Mejia et al. (2016) \\
\hline $\begin{array}{l}\text { Corporación Universitaria Autónoma del } \\
\text { Cauca }\end{array}$ & $\begin{array}{l}\text { Laboratorio de la Facultad Ciencias } \\
\text { ambientales y Desarrollo Sostenible }\end{array}$ & 1 & Malaver and Muñoz (2018) \\
\hline \multirow[t]{2}{*}{$\begin{array}{l}\text { Instituto de Investigaciones Marinas y } \\
\text { Costeras IVEMAR }\end{array}$} & $\begin{array}{l}\text { Laboratorios de Calidad Ambiental } \\
\text { Marina }\end{array}$ & 1 & Garcés-Ordoñez and Espinoza-Díaz (2019) \\
\hline & Programa Calidad Ambiental Marina & 1 & Narváez-Flórez et al. (2008) \\
\hline $\begin{array}{l}\text { Fundación Universitaria Tecnológico } \\
\text { Comfenalco }\end{array}$ & $\begin{array}{l}\text { GIA-Grupo de Investigaciones Ambien- } \\
\text { tales }\end{array}$ & 1 & Echeverri Jaramillo et al. (2011) \\
\hline $\begin{array}{l}\text { Ecopetrol-Instituto Colombiano del } \\
\text { Petróleo }\end{array}$ & Not information available & 1 & Vargas et al. (1996) \\
\hline
\end{tabular}

Acknowledgements DRG received financial support for her postdoctoral research from Ministerio de Ciencia Tecnología e Innovación-Minciencias, Colombia, Grant No. 811-2018.

Author contributions MM-S and DR-G performed the literature search and data analysis and wrote the first draft of the manuscript. DRG came up with the idea for the article and critically reviewed the manuscript drafts. All the authors read and approved the final manuscript.

Funding This work was funded by Universidad Santiago de Cali, Grants Nos. 934-621119-319 and 934-621120-G03 to DRG.

Data availability Not applicable.

Code availability Not applicable.

Material availability Not applicable.

\section{Declarations}

Conflict of interest The authors declare that they have no competing interests.

Ethical approval Not applicable.

Consent to participate Not applicable.

Consent for publication Not applicable.

Open Access This article is licensed under a Creative Commons Attribution 4.0 International License, which permits use, sharing, adaptation, distribution and reproduction in any medium or format, as long as you give appropriate credit to the original author(s) and the source, provide a link to the Creative Commons licence, and indicate if changes were made. The images or other third party material in this article are included in the article's Creative Commons licence, unless indicated otherwise in a credit line to the material. If material is not included in the article's Creative Commons licence and your intended use is not permitted by statutory regulation or exceeds the permitted use, you will need to obtain permission directly from the copyright holder. To view a copy of this licence, visit http://creativecommons.org/licenses/by/4.0/.

\section{References}

Ahmed F, Fakhruddin A (2018) A review on environmental contamination of petroleum hydrocarbons and its biodegradation. Int J Environ Sci Nat Resour 11:63-69. https:// doi.org/10.19080/IJESNR.2018.11.555811

Álvares S, Arango M, Leudo A, et al (2016) Evaluación de microorganismos viables en medios suplementados con hidrocarburos. Institución Universitaria Colegio Mayor de Cundinamarca. Retrieved from https://www.colmayor.edu. co/wp-content/uploads/2019/08/2-17-evaluacion-micro organismos.pdf. Accessed 1 June 2021

Álvarez-Mejia C, Aguirre-Gomez E, Navarro-Garrido A, Lopez-Ramirez V (2016) Degradación microbiana de gasolina en suelos agrícolas de Pueblo Nuevo, Guanajuato. Rev Ciencias Nat y Agropecu 3:24-32

Arenas-Piza D (2018) Procesos de biodegradación para el tratamiento de derrames de petróleo por medio de Pseudomonas. Fundación Universidad de América. Retrieved from https://repository.uamerica.edu.co/bitstream/20.500. 11839/7130/1/392273-2018-I-GA.pdf. Accessed 1 June 2021

Arenas-Soler J (2020) Evaluación de la capacidad de biodegradación de diésel por células libres e inmovilizadas de Chromobacterium violaceum. Universidad de La Salle. Retrieved from https://ciencia.lasalle.edu.co/ing_ambie ntal_sanitaria/1871. Accessed 1 June 2021

Arrieta-Ramírez O, Rivera-Rivera A, Arias-Marin L et al (2012) Biorremediación de un suelo con diesel. Gestión y Ambient 15:27-40

Barrios-Ziolo LF, Robayo-Gómez J, Prieto-Cadavid S, Cardona-Gallo SA (2015) Biorremediación de suelos contaminados con aceites usados de motor. Rev CINTEX 20:69-96 
Benavides-López J, Quintero-Vizcaíno G, Liliana-Guevara A et al (2006) Bioremediación de suelos contaminados con hidrocarburos derivados del petróleo. Nova 4:82-90. https://doi.org/10.22490/24629448.351

Camargo-Millán G, Acero-Pérez N (2007) Ensayo piloto de biorremediación de suelos contaminados por hidrocarburos. Fase 11. Rev Fac Ing 16:69-79

Camenzuli D, Freidman B (2015) On-site and in situ remediation technologies applicable to petroleum hydrocarbon contaminated sites in the Antarctic and Arctic. Polar Res 34:24492. https://doi.org/10.3402/polar.v34.24492

Das N, Chandran P (2011) Microbial degradation of petroleum hydrocarbon contaminants: an overview. Biotechnol Res Int 2011:1-13. https://doi.org/10.4061/2011/941810

De La Rosa Martinez D, Rabelo-Florez R (2020) Bacterias biodegradadoras de hidrocarburos. Biociencias 2:1-12

de Mesa J, Quintero G, Vizcaíno A et al (2006) Bioremediación de suelos contaminados con hidrocarburos derivados del petróleo. Nova 4:82-90. https://doi.org/10.22490/ 24629448.351

Delgado-Vallejo A (2017) Gestión de un proceso de biorremediación bacteriana de suelo contaminado con crudo en condiciones anaeróbicas. Universidad Nacional de Colombia, Medellín. Retrieved from https://repositorio. unal.edu.co/handle/unal/63123. Accessed 1 June 2021

Doria-Argumedo CJ (2018) Degradación de residuos aceitosos provenientes de actividades mineras en la Guajira, Colombia. Rev Politéc 14:42-51. https://doi.org/10.33571/rpoli tec.v14n26a4

Duran-Rincon M, Contreras N (2006) Alternativa de tratamiento para tierras fuller contaminadas con aceite dielectrico. Sci Tec 3:419-424. https://doi.org/10.22517/23447 214.6329

Echeverri Jaramillo GE, Manjarrez Paba G, Cabrera Ospino M (2011) Aislamiento de bacterias potencialmente degradadoras de petróleo en hábitas de ecosistemas costeros en la Bahia de Cartagena, Colombia. Nova, Publicación Científica En Ciencias Biomédicas 8:76-86

Galvis-Ibarra V (2019) Evaluación de la bioaumentación empleando consorcios de hongos y bacterias en la degradación de borras aceitosas. Pontificia Universidad Javeriana. Retrieved from https://repository.javeriana.edu.co/ handle/10554/47160. Accessed 1 June 2021

Gamba KT, Pedraza AM (2017) Evaluación de estrategias de biorremediación para el tratamiento de aguas residuales industriales contaminadas con aceites usados. Ingeciencia 2:18-30

Garcés-Ordoñez O, Espinoza-Díaz L (2019) Contaminación por hidrocarburos en sedimentos de manglar del estuario del río Mira, Pacífico colombiano, afectados por derrames de petróleo crudo. Boletín Investig Mar y Costeras 48:159-168. https://doi.org/10.25268/bimc.invemar.2019. 48.1 .763

García E, Roldan F, Garzón L (2011) Evaluación de la bioestimulación (nutrientes) en suelos contaminados con hidrocarburos utilizando respirometría. Acta Biol Colomb 16:195-208

Garzón J, Rodriguez-Miranda J, Hernández-Gómez C (2017) Aporte de la biorremediación para solucionar problemas de contaminación y su relación con su desarrollo sostenible. Univ y Salud 19:309-318. https://doi.org/10. 22267/rus.171902.93

Gomez M, Hurtado C, Dussán J et al (2006) Determinación de la capacidad de degradación de compuestos orgánicos persistentes por bacterias marinas aisladas de sedimentos en el caribe colombiano. Actual Biol 28:125-137

Gómez W, Gaviria J, Cardona-Gallo S (2009) Evaluación de la bioestimulación frente a la atenuación natural y la bioaumentación en un suelo contaminado con una mezcla de gasolina-diesel. Dyna 76:83-93

Gómez-Rivera M, Kopitko M (2012) Estudio comparativo de la biodegradación de hidrocarburos totales del petróleo (HTP'S) a través de la atenuación natural, bioestimulación en un suelo contaminado. Universidad Pontificia Bolivariana, Bucaramanga. Retrieved from https://repository.upb. edu.co/handle/20.500.11912/2022. Accessed 1 June 2021

Hernández-Rodríguez D (2020) La dualidad del petróleo en Colombia: positivo futuro económico basado en su dependencia. Universidad EAN. Retrieved from https:// repository.ean.edu.co/handle/10882/10516. Accessed 1 June 2021

Hernández Ruiz G, Álvarez Orozco N, Ríos Osorio L (2017) Biorremediación de organofosforados por hongos y bacterias en suelos agrícolas : revisión sistemática. Corpoica Cinec Tecnal Agropecu 18:139-159

Kolsal F, Akbal Z, Liaqat F et al (2017) Hydrocarbon degradation abilities of psychrotolerant Bacillus strains. AIMS Microbiol 3:467-482. https://doi.org/10.3934/microbiol. 2017.3.467

Kopytko M, Ibarra-Mojica D (2009) Evaluación del potencial de biodegradación de hidrocarburos torales del petróleo (TPH) en suelos contaminados procedentes de Petrosantander (Colombia) Inc. Rev Cient La Univ Pontif Boliv 3:35-46. https://doi.org/10.18566/puente.v3n1.a04

Ławniczak L, Wozniak-Karczewska M, Loibner A et al (2020) Microbial degradation of hydrocarbons-basic principles for bioremediation: a review. Molecules 25:1-19. https:// doi.org/10.3390/molecules25040856

Lima S, Oliveira A, Golin R et al (2020) Isolation and characterization of hydrocarbon-degrading bacteria from gas station leaking-contaminated groundwater in the Southern Amazon, Brazil. Braz J Biol 80:354-361. https://doi.org/ 10.1590/1519-6984.208611

Logeshwaran P, Megharaj M, Chadalavada S et al (2018) Petroleum hydrocarbons $(\mathrm{PH})$ in groundwater aquifers: an overview of environmental fate, toxicity, microbial degradation and risk-based remediation approaches. Environ Technol Innov 10:175-193. https://doi.org/10.1016/j.eti. 2018.02.001

Lozano N (2005) Biorremediación de ambientes contaminados con petróleo. Tecnogestion Una Mirada Al Ambient 2:51-55

Malaver Y, Muñoz J (2018) Degradación de hidrocarburos totales del petróleo a partir de la población microbiana contenida en estiércol bovino. Corporación Universitaria Autónoma del Cauca. Retrieved from https://repositorio. uniautonoma.edu.co/handle/123456789/307. Accessed 1 June 2021

Marquez-Rocha F, Hernandez-Rodriguez V, Lamela M (2001) Biodegradation of diesel oil in soil by a microbial consortiun. Water Air Soil Pollut 128:313-320 
Martínez-Rivera A (2018) Biorremediación bacteriana de suelo contaminado con fluidos y residuos de perforación mediante diferentes métodos. Universidad Nacional de Colombia, Medellín. Retrieved from https://repositorio.unal.edu. co/handle/unal/63429. Accessed 1 June 2021

Mendizabala A, Holmes J, Ortiz N et al (2021) A hotspot analysis of critical hydrocarbons infrastructure in Colombia: ELN (Ejército de Liberación Nacional) and FARC (Fuerzas Armadas Revolucionarias de Colombia) attacks on Colombian pipelines. Appl Geogr. https://doi.org/10. 1016/j.apgeog.2020.102376

Mezquida R, Oviedo L, Lara C (2015) Biodegradation in vitro of diesel bilge watrs using a minrobial Native consortium isolated from Cordoba, Colombia. Biotecnol Apl 32:2201-2205

Minciencias (2019) Gobierno Nacional presenta evolución de la investigación y la innovación durante 2018. https:// minciencias.gov.co/sala_de_prensa/gobierno-nacionalpresenta-evolucion-la-investigacion-y-la-innovaciondurante-2018. Accessed 1 June 2021

Minenergía (2021) Reservas de crudo se mantienen en 6.3 años, pese a fuerte caída del precio en 2020; reservas de gas bajan por tercer año consecutivo, llegando a 7.7 años. https://www.minenergia.gov.co/historico-de-noticias? idNoticia $=24291206$. Accessed 1 June 2021

Narváez-Flórez S, Gómez M, Martínez M (2008) Selección de bacterias con capacidad degradadora de hidrocarburos aisladas a partir de sedimentos del caribe Colombiano. Bol Investig Mar y Costeras 37:61-75. https://doi.org/10. 25268/bimc.invemar.2008.37.1.182

Nisperuza-Vidal A, Montiel-Aroca M (2010) Caracterización y evaluación de cepas bacterianas nativas con capacidad hidrocarburolítica del pozo petrolero de San Sebastián, Lorica, departamento de Córdoba. Universidad de Cordoba, Monteria. Retrieved from https://repositorio.unico rdoba.edu.co/handle/ucordoba/969. Accessed 1 June 2021

Ñuste-Cuartas D, Paredes-Cuervo D, Cubillos-Vargas J (2014) Bioremediation for degradation of total hydrocarbons present in the sediments of a fuel service station. Rev Técnica La Fac Ing Univ Zulia 37:20-28

Ordoñez-Burbano DE, Abella-Medina CA, Echeverry-Tamayo A et al (2018) Biodegradación de hidrocarburos alifáticos saturados por microorganismos aislados de suelo contaminado con derivados del petróleo. Rev Cienc 22:33-44. https://doi.org/10.25100/rc.v22i2.7917

Pandey AK, Dubey V (2012) Biodegradation of azo dye Reactive Red BL by Alcaligenes sp. AA09. Int J Eng Sci $1: 54-60$

Pardo-Díaz S, Rojas-Tapias D, Roldan F et al (2017) Biodegradación de fenol en aguas tratadas de la industria petrolera para reutilización en cultivos agrícolas. Rev Biol Trop 65:685-699. https://doi.org/10.15517/RBT.V65I2.23992

Perdomo-Rojas M, Pardo-Castro J (2004) Efecto de la adición de fertilizantes inorgánicos compuestos en la degradación de hidrocarburos en suelos contaminados con petróleo-a nivel laboratorio. Universidad de la Salle. Retrieved from https://ciencia.lasalle.edu.co/ing_ambiental_sanitaria/ 1560/. Accessed 1 June 2021

Pérez-Robles S, Silvia-Melo I, Peñuela-Mesa G, Cardona-Gallo S (2015) Evaluación de biocombustibles e hidrocarburos del petróleo (gasolina y diesel) en un suelo: procesos de transporte y biorremediación. Rev EIA 12:21-46. https:// doi.org/10.14508/reia.2014.11.E2.21-46

Pino N, Carvajal S, Gallo A, Peñuela G (2012) Comparación entre bioestimulación y bioaumentación para la recuperación de suelos contaminados con diesel. Prod Limpia 7:101-108

Pinto-Varón D, Sánchez-Vargas V (2018) Biorremediación de suelos contaminados por hidrocarburos mediante la utilización de diferentes cepas bacterianas a escala de laboratorio. Universidad Libre. Retrieved from https://repos itory.unilibre.edu.co/handle/10901/15451. Accessed 1 June 2021

Quintana-Saavedra D, Cabrera M, Tous-Herazo G, Cheverry G (2012) Aislamiento de microorganismos oligotróficos degradadores de hidrocarburos en la bahía de Cartagena, Colombia. Boletín Científico CIOH 30:3-12. https://doi. org/10.26640/01200542.30.3_12

Renteria M, Rosero D (2019) Estudios sobre la biorremediación en Colombia. Hechos Microbiol 10:39-48. https:// doi.org/10.17533/udea.hm.v10n1a05

Reyes-Reyes MA, Puentes-Cala EA, Casanova-Montes EL et al (2018) Inmovilización de bacterias potencialmente degradadoras de petróleo crudo en matrices orgánicas naturales y sintéticas. Rev Interncional Contam Ambient 34:597609. https://doi.org/10.20937/rica.2018.34.04.04

Sales da Silva I, Gomes de Almeida FC, Padilha da Rocha e Silva N, Casazza A et al (2020) Soil bioremediation: overview of technologies and trends. Energies 13:1-25. https://doi.org/10.3390/en13184664

Silva E, Correa P, Almeida D et al (2018) Recovery of contaminated marine environments by biosurfactant-enhanced bioremediation. Colloids Surf B Biointerfaces 172:127135. https://doi.org/10.1016/j.colsurfb.2018.08.034

Suárez-Medellin L, Vives M (2004) Degradación de tolueno y xileno por bacterias nativas Colombianas y detección de los genes TodA y XylB, Universidad de los Andes, Bogota-Colombia. Universidad de los Andes. Retrieved from http://hdl.handle.net/1992/10350. Accessed 1 June 2021

Trujillo-Quintero H, Losada-Cubillos J, Rodríguez-Zambrano H (2017) Amazonia colombiana, petróleo y conflictos socioambientales. Rev Científica Gen José María Córdova 15:209-223. https://doi.org/10.21830/19006586.181

Trujillo-Toro M, Ramírez-Quirama J (2012) Biorremediación en suelos contaminados con hidrocarburos en Colombia. Rev Investig Agrar y Ambient y Ambient 3:33-48. https:// doi.org/10.22490/21456453.952

Truskewycz A, Gundry T, Khudur L et al (2019) Petroleum hydrocarbon contamination in terrestrial ecosystemsfate and microbial responses. Molecules 24:1-20. https:// doi.org/10.3390/molecules24183400

Valdivia-Anistro J, Eguiarte L, Souza V (2018) Ecological adaptability of Bacillus to extreme oligotrophy in the Cuatro Cienegas Basin. In: García-Oliva F, Elser J, Souza V (eds) Ecosystem ecology and geochemistry of Cuatro Cienegas Cuatro. Ciénegas Basin: an endangered hyperdiverse oasis. Springer, Cham

Vallejo V, Salgado L, Roldan F (2005) Evaluación de la bioestimulación en la biodegradación de TPHs en suelos contaminados con petróleo. Rev Colomb Biotecnol 7:87-78 
Vallejo V, Yanine H, Roldán F (2010) Aplicación de sales de tetrazolio de nueva generación (XTT) para la estimación de la densidad de microorganismos degradadores de hidrocarburos empleando la técnica del número más probable. Acta Biológica Colomb 15:75-90

Vallejo-Quintero V, Sandoval-Cobo J, Garagoa-Barahona S, Bastos-Arenas J (2016) Evaluación del efecto de la bioestimulación sobre la biorremediación de hidrocarburos en suelos contaminados con alquitrán en Soacha, Cundinamarca-Colombia. Acta Agronómica 65:354-361. https://doi.org/10.15446/acag.v65n4.51013

Vargas M, Ramírez N, Rueda S, Sánches F (1996) Isolation of microorganisms with capability to degrade polycyclic aromatic hydrocarbons (PAH s). CT\&F-Ciencia, Tecnol y Futur 1:45-53

Vásquez M, Gerrero-Figueroa J, Quintero A (2010) Biorremediacón de lodos contaminados con aceites lubricantes usados. Rev Colomb Biotecnol 12:141-157

Velásquez-Arias JA (2017) Contaminación de suelos y aguas por hidrocarburos en Colombia. Análisis de la fitorremediación como estrategia biotecnológica de recuperación. Rev Investig Agrar y Ambient 8(1):151-167

$\mathrm{Xu}$ X, Liu W, Tian S et al (2018) Petroleum hydrocarbondegrading bacteria for the remediation of oil pollution under aerobic conditions: a perspective analysis. Front Microbiol 9:1-11. https://doi.org/10.3389/fmicb.2018. 02885

Yanine H (2010) Evaluación de la diversidad de bacterias degradadoras de hidrocarburos aisladas de suelos de las cuencas de los ríos Otún y la Vieja. Universidad Nacional de Colombia. Retrieved from https://repositorio.unal.edu. co/handle/unal/70322. Accessed 1 June 2021

Zhang P, Chen Y (2017) Polycyclic aromatic hydrocarbons contamination in surface soil of china: a review. Sci Total Envirom 605-606:1011-1020. https://doi.org/10.1016/j. scitotenv.2017.06.247

Publisher's Note Springer Nature remains neutral with regard to jurisdictional claims in published maps and institutional affiliations. 